H.B. Mortensen * S. Hartling* ${ }^{\star}, K . E$. Petersen from The Danish Study Group of Diabetes in Childhood.

AGE AND SEX RELATED EFFECT ON HbA LEVELS IN CHILDREN WITH INSULIN DEPENDEN'T DIABETES MELLITUS (IDDM).

In a nationwide screening for $\mathrm{HbA}_{1 \mathrm{C}}$ in Denmark all 22 diabetic paediatric departments participated. During a period of 4 months a total number of $791 \mathrm{chil-}$ dren (approximately $75 \%$ of total) was included. Among these 319 were $\leq 12 y$ and 472 between 12 and $18 \mathrm{y}$. Mean $\mathrm{HbA}_{1 \mathrm{c}}$ for children $\leq 12 \mathrm{y}$ was $8.9 \% \pm 1.5$ (SD), mean insulin dosage being $0.70 \mathrm{U} / \mathrm{kg} / 24 \mathrm{~h}$, range $0.04-2.24 \mathrm{U} / \mathrm{kg} / 24 \mathrm{~h}$. For children between 12 and $18 \mathrm{y}$ mean $\mathrm{HbA}_{1 \mathrm{C}}$ was $9.4 \% \pm 2.0$ (SD) (compared to children $<12 \mathrm{Y}, \mathrm{p}<0.001)$ mean insulin dosis being 0.85 $\mathrm{U} / \mathrm{kg} / \overline{2} 4 \mathrm{~h}$, range $0.00-3.24 \mathrm{U} / \mathrm{kg} / 24 \mathrm{~h}$. Among the 319 children $\leq 12 y, 174$ were boys and 145 were girls. For both groups mean $\mathrm{HbA}_{1 \mathrm{c}}$ was $8.9 \pm 1.5$ (SD). Mean insulin dosage for boys was $0.66 \mathrm{U} / \mathrm{kg} / 24 \mathrm{~h}$ in contrast to $0.74 \mathrm{U} / \mathrm{kg} / 24 \mathrm{~h}$ for the girls. In the group of children between 12 and $18 \mathrm{y}$ mean $\mathrm{HbA}_{1 \mathrm{c}}$ among 250 boys was $9.5 \% \pm 2.0$ (SD) and for the remaining 222 girls $9.9 \% \pm 1.9(\mathrm{SD}) \quad(\mathrm{p}<0.001)$. Insulin dosis was again consistently higher for the girls being 0.89 $\mathrm{U} / \mathrm{kg} / 24 \mathrm{~h}$ compared to $0.80 \mathrm{U} / \mathrm{kg} / 24 \mathrm{~h}$ for the boys. In spite of increased insulin dosage $\mathrm{HbA}_{1 \mathrm{c}}$ increased with age especially in girls, suggesting age and sex related changes in insulin sensitivity.

E.Vicens-Calvet, J.M. Cuatrecasas* (Introd. by E. Vicens-Calvet). for the Study Collaborative Group.

66 Kabi-Fides. Barcelona.

SPANISH MULTICENTRIC TRIAL ON SOMATREM.

During 1985-86 a multricentric trial to evaluate the safety and efficacy of Somatrem (SomatonormR) in children with growth hormo ne deficiency (GHD) was performed in Spain. 49 patients "new" as well as previously treated ("old"), with peak plasma hGH $<7 \mathrm{ng} / \mathrm{ml}$ height $\mathrm{SD}<-2.0$ for chronological age (CA), growth velocity (CV) $<4$ cms/year, bone age (BA) < 10 "years" in girls and 11 "years" in boys and idiopathic were involved in the trial. Dosage was 4 IU, 3 times a week i.m. EFFICACY: In "new" patients (N=2l) GV changed from $3.39 \mathrm{~cm} / \mathrm{yr}$ to 9.22 in the "young group" ( $\mathrm{CA}<10 \mathrm{yrs}$ ) and from 2.52 to 6.62 in the "prepuberal" group ( $\mathrm{CA}: 10-16$ yrs). In "old" patients $(\mathrm{N}=28)$, the majority of them, irregularly trea ted, the change in GV was from $4.8 \mathrm{~cm} / \mathrm{yr}$ to 6.62 ("young group") and 3.15 to 6.02 (prepuberal group). BA evolved parallely to C.A. with an improvement of adult heigth prognosis. SAFETY: The study of hGH antibodies (hGH-ab) in new patients showed a $29 \%$ of positive cases from the end of first quarter reaching a plateau between 36.6-28.5\% later. In the "old" group the percentage was significantly less. The Binding capacity of hGH-ab was very low ( $M=0.05 \mathrm{mg} / \mathrm{l}$ ) E.coli polypeptide-ab fluctuated throughout treatment with no clear correlation with hGH-ab. CONCLUSION: Somatrem is as effective in patients with GHD as pit-hCH was and is a safe product since the $a b$ found produce no deleterious metabolic effects and do not interfere with growth.

P H W Rayner (British Collaborative Study) Institute of Child Health, University of Birmingham, England.

\section{TREATMENT OF HYPOPITUITARISM WITH RECOMBINANT} MET-HGH (LILLY)

Recombinant Met-HGH (Lilly) has been used to treat 22 children with hypopituitarism. Mean age 7.1 yrs (range 3.7-12.1), 14 boys, 8 girls. In 16 children, an isolated GH deficiency was present. One child withdrew from treatment after 6 months, the remainder completed a minimum of 1 year. Met-HGH was given by $\mathrm{SC}$ injection, in 3 doses per week, each of $0.06 \mathrm{mg} / \mathrm{kg}$ body weight, up to a maximum of $8.0 \mathrm{mg} /$ week. The growth response is summarised below, $(A=$ pretreatment, $B=1$ year $)$ :

$\begin{array}{lcccc} & H t \text { Vel } & H t \text { SDS } & \text { Ht Vel SDS } & \\ \text { A: } & 4.2 & -3.6 & -1.96 & \text { mean } \\ \text { B: } & 1.0 & 1.1 & 1.27 & 1 \text { SD } \\ & 9.0 & -2.7 & 3.93 & \text { mean } \\ & 2.1 & 1.1 & 2.75 & 1 \text { SD }\end{array}$

Full haematological and biochemical screening performed 3 monthly showed no abnormalities. No allergic reactions were seen. GH antibody development was variable, mean (\% bound) levels rising from $2.1 \%$ at 1 month to $29.2 \%$ at one year, we 11 below levels previously associated with loss of therapeutic effect. ECP antibodies were detectable in all patients, but did not show a significant increase in titre. IGF-l levels increased in all children but showed no significant correlation with growth response. Recombinant Met-HGH is an effective treatment for $\mathrm{GH}$ geficiency. No significant side effects have been encountered
M.Zachmann, M.Muritano*,T.Torresani, L.H.Rasmussen* Department of Pediatrics, University of Zurich,

Switzerland representing 14 European centers, and Nordisk Gentofte, Denmark.

RESULTS OF TREATMENT WITH RECOMBINANT HUMAN GROWTH HORMONE WITHOUT METHIONINE ( $r$-hGH) IN PATIENTS (PTS) WITH GROWTH HORMONE DEFICIENCY (GHD)

255 pts with GHD ( 180 boys, 75 girls, age $0.5-19.9(11.1+/-3.7)$, bone age $0-17(8.9+/-3.5)$ yrs, height SDS for chronologic age -2.8 $+/-1.0)$ are currently treated with $r-h G H ~ s c(12.6+/-1.8$ IU and 5.8 $+/-1.3$ injections/week). By mid-april, 181 pts had been treated for 3,89 for 6,27 for 9 , and 11 for 12 months. 122 had isolated GHD, the others additional defects with adequate replacement (including 29 craniopharyngeomas, 19 other organic causes and irradiation). 93 had been transferred from pit- or met-hGH. Routine blood analyses were normal before and on treatment. With exception of mild local burning, no side-effects were noted. Mean height velocities (cm/yr, 3 month periods, SEM 0.2-0.9) were:

Patients: all new transfer isol. comb. organic

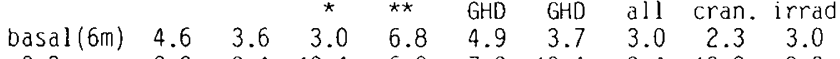

$\begin{array}{llllllllll}0-3 \mathrm{~m} & 9.0 & 9.4 & 10.4 & 6.8 & 7.8 & 10.4 & 9.4 & 10.2 & 9.0\end{array}$

$\begin{array}{lllllll}3-6 \mathrm{~m} & 7.9 & 9.3 & 8.2 & 6.4 & 7.7 & 8.4\end{array}$

$\begin{array}{lllllll}6.9 \mathrm{~m} & 7.3 & 8.3 & 7.2 & 7.0 & 7.3 & 7.4\end{array} \quad *=6 \mathrm{~m}$ interval

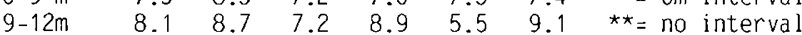

IGF 1 increased from $14(6-26)$ to $25(12-47) \mathrm{nmol} / \mathrm{l}(6 \mathrm{~m}$, without trans fer**). hGll antibodies were found in 2 new (3-9 months) and 14 transfer pts(before $r$-hGH).E.coli protein antibodies did not increase. It is concluded that $r$-hGH is effective and safe in GHD.

P. Stubbe ${ }^{1}, N$. Stahnke ${ }^{2}$ and study group. Department of Pediatrics, University of Goettingen ${ }^{1}$ and Hamburg ${ }^{2}$, FRG.

69 R-HGH OF MAMMALIAN CELL ORIGIN FOR THE TREATMENT OF GROWTH HORMONE (GH) DEFICIENCY IN CHILDREN.

Biogenetically produced authentic $\mathrm{GH}$ ( $r-\mathrm{HGH}$ ) of mammalian cell origin was used in a multicenter treatment trial involving GH deficient children from Austria, FRG, GER and Switzerland after approval by ethical committees. GH was applied S.C. daily in a dose of $12 \mathrm{U} / \mathrm{m}^{2}$ /week. Previously with GH treated (group T) and untreated (group U) patients were included. 65 patients met the selection criteria. Group $U$ consisted of 20 males and 9 females, mean age $7.59 \pm 4.1$ (SD) y, mean bone age (BA) $5.12 \pm 3.43$ y. Group T enclosed 28 males, 8 females, mean age $9.66 \pm 3.48$ y, mean BA 6.57 $\pm 3.01 \mathrm{y}$, pituitary GH was stopped for a period of time before r-HGH started. Results: After 6 months of treatment: Group U: Mean growth velocity increased from $3.06 \pm 0.81$ to $10.26 \pm 2.5 \mathrm{~cm} / \mathrm{y}$, mean height standard deviation score (SDS) for age was reduced from $-3.45 \pm 1.27$ to $-2.97 \pm 1.1$ and height age (HA): BA ratio increased from $1.02 \pm 0.24$ to $1.12 \pm 0.33$. Group $T$ : Growth velocity increased from $3.16 \pm 1.98$ to $8.8 \pm 2.35 \mathrm{~cm} / \mathrm{y}$, mean height SDS was reduced from $-2.73 \pm 1.91$ to $-2.42 \pm 1.76$. HA: BA ratio improved from $0.97 \pm 0.27$ to $1.08 \pm 0.26$. In both groups Somatomedin $C 1$ vels rose. One of $65 \mathrm{child}$ ren developed GH antibodies, no anti-

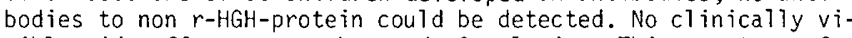
sible side effects were observed. Conclusion: This new type of $r$-HGH is effective and an alternative to $r$-HGH produced in E. coli bacteria.

O. Butchandt, K. Kruse, E. Heinze, H. Frisch Childrens Hospitals of the Universities of Munich, Würzburg and Ulm, Germany, Vienna, Austria.

ONE YEAR LXPERIENCE WITH BIOSYNTHETIC HOMOLOGOUS HUMAN GROWTH HORMONE IN 81 CHILDREN WITH GROWTH HORMONE DEFICIENCY :

Biosynthetic homologous human growth hormone (recombinant DNA) produced by Eli lilly was given to 81 children treated for growth hormone deficiency (GHD) in 26 centers. Crowth improved in all of them: 25 newly diagnosed patients increased their growth rate from $3.6 \pm 1.7$ to $11.9 \pm 2.0 \mathrm{~cm} / \mathrm{y} .14$ patients txansferred from pituitary to biosynthetic hGll continued to grow with a velocity of $5.7+2.2 \mathrm{~cm} / \mathrm{y}$ compared to $5.0+3.3$ $\mathrm{cm} / \mathrm{y}$ when given pit.-hGH, 42 patients with GHD receiving biosynth. hGH after an interruption of therapy for approx. one year grew with a velocity of $8.1+2.0 \mathrm{~cm} / \mathrm{y}$ on biosynth. hGH after a catch-down growth of $1.9 \mathrm{~cm} / \mathrm{y}$ from a pit.-hGH induced growth rate of $7.2 \pm 2.1 \mathrm{~cm} / \mathrm{y}$. The loss of growth during the interruption was not compensated for by catch-up growth. Therefore, any interruption of therapy may worsen the height prognosis. No side effects were observed and no specific antibodies against biosynth. hGH developed during therapy. Antibody-titers against $\mathrm{E}-\mathrm{Coli}$ peptides remained unchanged during therapy.

In conclusion, therapy with biosynthetic homologous hak is as effective as therapy with pit.-hGH and is safe. Therapy with hGH should not be interrupted during childhood and adolescence. 